\title{
(De)Stigmatization of Political Leadership: The Case of a Right-Wing Populist Presidential Candidate in the Finnish Media
}

\author{
Marke Kivijärvi, Tuomo Takala \\ School of Business and Economics, University of Jyväskylä, Jyväskylä, Finland \\ Email: marke.t.kivijarvi@jyu.fi, tuomo.a.takala@jyu.fi
}

How to cite this paper: Kivijärvi, M., \& Takala, T. (2020). (De)Stigmatization of Political Leadership: The Case of a Right-Wing Populist Presidential Candidate in the Finnish Media. Open Journal of Political Science, 10, 428-447.

https://doi.org/10.4236/ojps.2020.103026

Received: May 14, 2020

Accepted: July 6, 2020

Published: July 9, 2020

Copyright $\odot 2020$ by author(s) and Scientific Research Publishing Inc. This work is licensed under the Creative Commons Attribution International License (CC BY 4.0).

http://creativecommons.org/licenses/by/4.0/ (c) (i) Open Access

\begin{abstract}
In this article, we examine the discursive practices of (de)stigmatizing right-wing populist party leaders. We draw on a recent example from Finland by examining how the female presidential candidate of a right-wing populist party was portrayed in the Finnish media during the 2018 presidential campaign season. We examine the stigmatization by the press media and the stigma-management tactics used by the presidential candidate to resist stigmatization. The media representation of the right-wing party leader is highly tensioned, and the media positions her political leadership within the duality of charisma and stigma. In our analysis, we extend earlier literature by unveiling the emotional tensions inherent in portraying and (de)stigmatizing populist political leadership. The results highlight how religion, radical nationalism, and inappropriate expression of emotions are intertwined as the main sources for attributing stigma. In this case, the stigmatization of the leader occurs via threatening and ridiculing imagery and erosion of the leader's authority. Resistance to stigma occurs through distancing, emotional and moral argumentation, and attribution of strong leadership.
\end{abstract}

\section{Keywords}

Right-Wing Populism, Media Discourse, Stigma, Charismatic Leadership, Political Leadership

\section{Introduction}

In this paper, we address stigmatization and the responses to stigma originating from right-wing populist leaders in the media. Over the past few years, right-wing populism has been on the rise across Europe. In addition to major 
actors, such as the National Rally in France (formerly National Front) and the Party for Freedom in the Netherlands, we have witnessed the formation of new parties, for example, the Alternative for Germany. The public image of these "radical" parties often carries a social stigma, i.e., an undesirable quality that is "discrediting" (Goffman, 1963: p. 3). For example, Bos et al. (2011) point out that right-wing populist parties are associated with having radical ideas about immigration issues, thereby eliciting negative effects on their perceived legitimacy. Moreover, typically, the concept of populism is associated with negative images and stigma (Hatakka, 2018: p. 31). Thus, this paper examines how right-wing populist leadership is constructed through stigma and addresses the discursive means of removing shame.

The media are central spaces for public debates surrounding right-wing populism. Extant research on right-wing populist parties has addressed the roles of media (Bos et al., 2010, 2011; van Spanje \& Azrout, 2018) and party leaders' charisma (van der Brug \& Mughan, 2007) as key determinants of their electoral success. While the relationship between populist parties and the media is often complex, the parties can also use negative media publicity to their strategic advantage (Niemi \& Houni, 2018: p. 19). Analyzing media texts provides an access to one of the key spaces in which the public portraits and attitudes toward right-wing political leadership are established and negotiated.

In this paper, we are particularly interested in addressing how emotional elements intertwine with attributing stigma. Even though emotions play a significant role in both stigmatization and the stigmatized groups' reactions (Link et al., 2004; Creed et al. 2014), they have received relatively little scholarly attention. This paper's objective is to advance the understanding of emotions and stigma by examining (de)stigmatization in the context of political leadership. Emotions are fundamentally present in media (Koivunen, 2008), and their role is particularly emphasized in the case of socially controversial and contested phenomena, such as right-wing party politics. Emotions are central not only in the populist parties' rhetoric, but also evoke strong feelings among the journalists (Niemi \& Houni, 2018).

In our analysis, we examine media coverage of a right-wing populist party in Finland. More specifically, we examine how media articles portrayed Laura Huhtasaari, the female presidential candidate of the Finns Party, eight months before Finland's 2018 presidential election. The Finns Party has been described as a right-wing populist party that drives Euroskeptic and anti-immigration politics. The Finns Party breakthrough in the 2011 parliamentary election marks the beginning of right-wing populism gaining prominence in the Finnish political scenery. The Finns Party website describes the party as a "leading EU-skeptic party in Finland" (Finns Party, 2018). After the announcement of the presidential candidates' campaign launches, we paid attention to how the media responded to Huhtasaari's run for office. While we are accustomed to seeing several female politicians depicted positively in photos, we noticed that the photos of Huhtasaari were different. They often portrayed her with her chin up and 
mouth open, sometimes blurring parts of the picture and zooming in on her cross necklace. A story published by Yle, Finland's national public broadcasting company (Kinnunen, 2018), which features a personal story of Huhtasaari, showcases a caricature of her in the article's opening, with Huhtasaari wearing both a cross necklace and a Star of David pendant. While these perceptions were merely our personal reflections over morning coffee, we became interested in examining media representations in more depth. Huhtasaari is often compared to other far-right populist leaders, particularly Marine Le Pen, President of the National Rally (formerly National Front) party in France. The seemingly negative reporting around Huhtasaari served as the initial starting point for structuring this paper. Our analysis will focus on the stigmatization of the presidential candidate by the media, and the stigma-management strategies used by Huhtasaari in order to resist the stigma label.

The remainder of this paper is organized as follows. First, in our literature review we discuss how right-wing parties are associated with stigma, offer an outline of the role of emotions in attributing stigma, and introduce the strategies available for downplaying the effects of stigma based on extant research. Second, we introduce our data from the Finnish news media and describe the analysis process. We then present our findings using selected quotes from the media. Next, we discuss the implications of our results for future studies on stigma processes in the context of political leadership. Finally, we make summarizing points in the conclusion.

\section{Right-Wing Populism and (De)Stigmatization}

Stigma refers to an undesirable and "discrediting" quality (Goffman, 1963: p. 3) that may have the effect of preventing "collective action by actively discouraging identification with a group that could make claims against an institution" (Marx Ferree, 2004: p. 92). This paper addresses right-wing populist parties as an example of a group to which social stigma often is attached. Linden and Klandermans (2006) show how extreme-right activists experience social exclusion due to the negative associations attached to extreme-right social movements. van Spanje and Azrout (2018) examine how the Dutch Freedom Party was indirectly stigmatized in the media due to its cooperation with more extreme right-wing parties in the Europe, resulting in lower electoral support. Female right-wing leaders are particularly challenged by their double-standard deviance from the expected normalcy, i.e., being right-wing women and right-wing leaders, both of which are considered possible identity category violations (Downing, 2018).

Social stigma inexorably evokes social emotions, which can be regarded as "responses to others' violations of the social order" (Creed et al., 2014: p. 279). Thus, stigmatization can be viewed as an emotional response to someone breaking social norms within a given context. Indeed, as proposed by Link et al. (2004: p. 513), "emotional responses are critical to understanding the behavior of both stigmatizers and people who are recipients of stigmatizing reactions." Emotions can be a central part of stigmatizing, as "both other- and self-directed social 
emotions provide people with feedback on their own and others' standing as persons within a social group" (Creed et al., 2014: p. 279).

Stigmatization typically occurs with emotions, such as anger, irritation, anxiety, pity, and fear (Link et al., 2004: p. 513). In turn, shame is central to feeling stigmatized (Scheff, 1998). Shaming is elicited through ridicule (Marx Ferree, 2004). In addition to shame, the stigmatized person can feel embarrassment, fear, alienation, or anger (Link et al., 2004: p. 513). Emotions, such as contempt, shame, and disdain, are used to hold other people accountable for their character and conduct (Abramson, 2013: p. 210). Systemic shaming works as a form of power, as shaming induces the feeling of shame and includes threats of ostracization (Creed et al., 2014: p. 280).

Extant literature has identified several stigma-management strategies. On the one hand, stigma management entails managing the disclosure of stigmatizing information about oneself. On the other hand, it entails portraying one's identity in a positive light to mitigate and repudiate the repressive effects of stigma. Stigma-management strategies include, among other things, managing information about oneself, normalization, dissociating one's image from stigmatized identities, and avoiding interaction with people from non-stigmatized groups (Anspach, 1979; Snow \& Anderson, 1987). Coping with stigma can occur when those who are stigmatized proudly proclaim their stigmatized identity and espouse the stigmatizing aspects of their personas (Goffman, 1963) through advocacy (e.g., Taub et al., 2004). Employing an extension strategy, a stigmatized individual can escape stigmatization by using deflection and disidentifiers to redirect attention from the stigmatizing aspects (Goffman, 1963). A normalization strategy (Goffman, 1963) portrays the stigmatized individual in a positive light and aims to convey his/her "normality." In their study of prisoners, Toyoki and Brown (2014) identified the use of three stigma-management strategies: appropriation (e.g., reframing the "prisoner" label), drawing on discourses of coveted social roles (e.g., emphasizing fatherhood), and morality (being a moral agent despite the prisoner label). Earlier research has examined the coping strategies used by extreme-right activists, suggesting that these can involve taking pride in their stigma, denial, and distancing themselves from negative associations (Linden \& Klandermans, 2006). Based on our review of earlier studies, we find that there is a need to further examine how social stigma applies to political leadership, how emotions are intertwined with stigmatization, and how people cope with stigma in political leadership where the leaders are under the continuous public gaze of their voters, the wider public, and the media.

\section{Data and Methodology}

The empirical focus of this study is the Finnish Finns Party (formerly the True Finns Party), which is known for its Euroskeptic and anti-immigration agenda. The party experienced its first electoral success in the 2011 parliamentary election, and the victory that made them the third largest party was proudly touted as the "big bang" ("jytky" in Finnish) by the party’s long-serving chair, Timo 
Soini. Four years later, as a result of the 2015 general election, the party joined the governmental coalition as the nation's second largest party. The party's electoral successes have provoked social controversy and mockery, resulting in very few people publicly admitting their support for it. In the Finnish language, the Finns Party is often referred to as "Persut" in colloquial terms (an abbreviation of the party's Finnish name "Perussuomalaiset"). While this term has been used by party representatives and their opponents, it has morphed into a derogatory term.

For a long time, the Finns Party was associated with Timo Soini, who led it from 1997. In the summer of 2017, Soini announced that he was stepping down as the party's leader. In 2017, the Finns Party split: in the aftermath of electing Jussi Halla-aho as the party chair in June 2017, the party was divided into two political camps, and moderate members of the Finns Party formed a new parliamentary group, today known as the Blue Reform (Sininen tulevaisuus). While the Blue Reform continued as a member of the government coalition, the Finns Party was forced into an opposition position. Under the leadership of Jussi Halla-aho, an anti-immigration hard-liner, the Finns Party was transformed into a "pariah party" (Arter, 2020: p. 262). We interpret that this was also significant in setting the tone for how the media reported on the party's 2018 presidential candidate.

This paper focuses on discursive, stigmatizing acts in the media, as well as the responses by the people that are stigmatized, through media coverage of the Finns Party's 2018 presidential candidate, Laura Huhtasaari. Our interest in media articles revolves around the realization that mass media wield significant power in creating shared realities by deciding what stories are told, and perhaps even what voices are silenced (Marx Ferree, 2004). Thus, media discourse engages in repression (Koopmans, 2005). Earlier extant research has indicated that the success of right-wing political parties is often dependent on their media coverage, which includes prominence (e.g., Bos et al., 2010, 2011). In this paper, we argue that it is important to pay attention to the media's role in "soft repression" (Marx Ferree, 2004: p. 92) of these controversial populist parties through stigmatization. Our focus on the party leader follows earlier analyses of the prominent role of the leader in a political party's electoral success (e.g., Bos et al., 2010). Moreover, our interest in examining stigma is rooted in our preliminary notions that most of the media reports on Huhtasaari have been negative, a tendency that has been ascribed to the news value and that fits with contemporary media logic in which scandal-focused news feeds and moralizing reporting on populist parties serve market needs (Hatakka, 2018: p. 46).

Huhtasaari was nominated as the vice president of the Finns Party during the party's split, and it was from this position that she became its presidential candidate. The previous male party leader, Timo Soini, had a fourth place showing in the 2012 presidential elections. Huhtasaari's campaign resulted in a third place showing in the first electoral round. The Finns Party's online publication, Suomen Uutiset, celebrated this electoral outcome as "historical" and called it as 
a "warning to old parties"; it also interpreted Huhtasaari's victory as a sign that "feminism and other all-embracing themes no longer appeal to voters" (Suomen Uutiset, January 29, 2018).

The Finnish presidential elections were held on January 28, 2018, and the selected timeframe of our analysis is the final eight months of the campaign season, i.e., June 2017 to January 2018. The articles were sourced from two major national news media in Finland: Helsingin Sanomat, Finland's largest subscription-based newspaper (by circulation) and Yle's digital services at Yle.fi, provided by the Finnish public service broadcaster Yleisradio (Yle). Helsingin Sanomat and Yle represent two of the largest mainstream media outlets in Finland, and they can be seen as representing elite media. Yle has the image of being a reliable media source. Yle's TV channels were ranked the second most reliable media source, with Yle's digital services ranking fifth (IRO Research, 2017). Both Helsingin Sanomat and Yle are examples of liberal media outlets in Finland; in the French national context, liberal media has been found to be more negative in their reporting of female right-wing leaders than conservative news press (Snipes \& Mudde, 2019). The articles were taken from the newspaper's online archives and Yle's website, using "Laura Huhtasaari" as the search term. We selected articles (including long reports, columns, and interviews) that specifically focused on Huhtasaari; we excluded short news stories with more generic takes on the party or governmental issues. Our data comprise 18 media articles from Helsingin Sanomat and 15 from Yle.

We analyzed the data using qualitative content analysis (Bryman \& Bell, 2011), and we followed the tradition of discourse analysis by paying attention to the argumentation and metaphoric expressions used to purport a particular representation (Chilton, 2004; Wodak \& Chilton, 2005) using the following steps. First, the data were analyzed by reading the articles and forming ideas about their overall storyline, e.g., how they depict Huhtasaari's character. The articles report two major storylines: one about a strong, rising figure, and the other about a controversial politician. These two aspects were often intertwined, as the articles acknowledged Huhtasaari's charismatic appeal among her supporters and the bemoaning of her frightening talks among opponents (e.g. Kinnunen, 2018). Indeed, during this first round of reading the data, we discovered that the articles contained both positive and negative evaluations of the presidential candidate's character, touting her charisma while generating stigma (see Steyrer, 1998). Thus, while utilizing archetypes of charismatic leadership, the articles also predominantly drew on exaggerated intensification of, and reversion from, prototypical leadership characteristics, such as dedication, sensitivity, tyranny, communicativeness, strength/masculinity, and intelligence (see Steyrer, 1998), when evaluating Huhtasaari, with the effect of attaching stigma to the party leader's portrait. While Steyrer's model is commonly utilized to examine charismatic leadership (e.g., Takala et al., 2013), in this paper, the semantic continuum of leadership sensitized us to the ways in which Huhtasaari is portrayed using both charisma and stigmatizing attributes; it also enabled us to address 
how the discrediting, i.e., stigmatizing, attributes, are presented in media reports on right-wing populist leadership and how these leaders manage stigma through their impression management strategies (possibly drawing on attributes of charisma).

In the second analytical round, we identified how stigmatizing appears in the articles. First, we examined the nature of stigma and stigmatizing practices; we also identified how Huhtasaari responded to stigmatizing. At this stage, we coded the articles based on the attributes that cause stigma, i.e., the types of attributes with maximum negative connotation in Steyrer's model. We determined that stigmatization was related to two main categories: religion and anti-immigrant/nationalist attitudes. Huhtasaari was typically described as holding extreme views; e.g. a sub-heading labels her as a "Creationist and an opinionated immigration opponent" (Niilola, 2017). Thereafter, we examined how Huhtasaari talked about stigma from her own and her party's perspectives, and how she responded to the stigmatizing aspects, paying attention to attribution and argumentation in discursive image management. During the next stage, which, in practice, was intertwined with the earlier stages, we sought to understand how the use of emotions ties in with the (de)stigmatization processes by addressing how the discourse produces different types of emotional effects (see Chilton, 2004 for the use of emotions in political discourse). We coded the articles for emotions and emotive responses, and we examined in detail how the media discourse drew on the discrediting attributes through emotive associations, and what kinds of evaluations they used to describe Huhtasaari. These typically revolved around the use of threat images. At this point, we also examined Huhtasaari's own use of stigma-management strategies and their emotional appeal. Huhtasaari, for example, resisted being labeled as a harsh opponent of sexual minorities by claiming how she "finds it absolutely terrible if someone has to feel ashamed of oneself" (Vartiainen, 2017). The identification of emotions necessitates inductive reasoning (e.g., Toubiana \& Zietsma, 2017), and we crosschecked our interpretations of a particular method of expression. The analysis illustrates how the media and Huhtasaari deploy the borderline attributes and emotional strategies, with the effect of stigmatizing and coping with the stigmatized-leader position.

In the next section, we present our findings on the (de)stigmatization using selected quotes from media texts. All the quotes were translated by the authors. The findings section first discusses stigmatization of Huhtasaari by the media, then points to the stigma-management strategies that Huhtasaari deployed.

\section{Creating a Controversial Character: From a Strong, Charismatic Party Leader to a Tunnel-Visioned, Nationalist Warrior}

\subsection{Construction of "Threat"}

In the analyzed media stories, Huhtasaari appears to be a strong character. In the 
news reports, she is described using phallic expressions, e.g., Yle's subheading "Entering presidential contest as a warrior of the party" (Kinnunen, 2018). This story reveals how "In the election for the first vice president, the first-season parliament representative, Laura Huhtasaari, humiliated Minister of Defense Jussi Niinistö" (referring to the number of votes she received).

She is portrayed as a strong, potent political actor-someone with the power to shape the political scene. Helsingin Sanomat (Silfverberg, 2017) describes Huhtasaari's confrontations with other politicians in the following manner:

On the afternoon in Parliament (during) question time, she clashed with Prime Minister Juha Sipilä. Sipilä was offended because Huhtasaari did not follow the joint frontier that the Prime Minister was aiming for [referring to the parliamentary groups' decision to condemn racist talk].

(...)

In Parliament, Huhtasaari turned the matter so that Finns Party "dooms terrorists' hate talk" (veered) toward Finnish and Western values.

Thus, Huhtasaari efficiently took control of the offered air space. (...)

Huhtasaari's strength is emphasized by using military metaphors (controlling the "air space"). The media often describe right-wing female leaders using traits that emphasize their masculinity and power (see Snipes \& Mudde, 2019). An image of a militant character who stops at nothing is established in the stories that describe how Huhtasaari has "fired full front both those who have resigned from the party, as well as the president of the Republic of Finland" (Niilola, 2017).

The Finnish media generated moral panic (e.g., Goode \& Ben-Yehuda, 2009) using threat imagery. This is illustrated by the following headline and lengthier quote from Yle (Säävälä, 2017) where politicians from other parties are given the authority to express their anxiety, fear, and disapproval of Huhtasaari's actions:

\section{"Shocking", "unpleasant speech", "dangerous" party leaders comment on Finns Party Huhtasaari’s Islamization talk [Main headline]}

(...)

\section{Huhtasaari envisioned threats of Islamization [article subheading]}

Instead of calming down others, Huhtasaari elicited threatening images of Islamization approaching Finland.

Islamization refers to (the) state turning toward Islam. An example of such a state is Iran. In Huhtasaari's opinion, Finland, thus, threatens to become a state where drinking alcohol, infidelity, or theft could be punished by stoning or amputation.

In the excerpt presented above, the headline attributes stigma to Huhtasaari using vocabulary that clearly taints her political viewpoints as condemned by others in power. Huhtasaari's reliability as a party leader is targeted by referring to her inability to bring order, and portraying her as someone who brings uncertainty. Interestingly, the media use "threat" talk to stir emotions in two ways. 
First, they refer to the threat that Huhtasaari supposedly poses. Second, by selecting rather extreme and frightening examples concerning Iran, the media use these threats to explain Huhtasaari's extreme views. By selecting specific examples ("amputation", "stoning"), the media convey an image of irrationality in Huhtasaari's politics. From the text, it is not evident if these specific examples are paraphrased from Huhtasaari. Yet, for Finnish readers, stoning and amputation possibly convey the idea of the ontological "other," i.e., strange cultures that we might never imagine on our own. Demonizing aspects of other cultures can be interpreted as a threat to society (Nohrstedt, 2010).

\subsection{Questioning Leader Authority}

In constructing stigma, a predominant, discursive strategy was to question Huhtasaari's authoritativeness. Bos et al. (2011: p. 188) refer to how a politician's authoritativeness "refers to how knowledgeable a politician is about the political topics discussed." This might be produced, for example, by referring to statistics and information-source citations. The media portray Huhtasaari as focusing on trivial aspects without possessing knowledge of the issue. An article appearing in Helsingin Sanomat (Teittinen, 2017) suggests that "Huhtasaari's political speech is full of symbolic anecdotes". Yle's article (Roslund, 2018) that recites three expert's evaluation of Huhtasaari's performance in a political debate broadcast was headlined as "Huhtasaari lacked knowledge in questions of external and safety policy - "to mention attendance to a prayer breakfast as a merit for foreign policy did not help to relieve the impression". This, we argue, served to belittle Huhtasaari's authority by bridging her lack of knowledge with her religious engagements in the main headline. The stories build on her controversial persona by referring repeatedly to her extreme views.

Huhtasaari's leadership authority was further reduced by portraying her as a tunnel-visioned, dogmatic leader, rather than someone who would carefully weigh different opinions before making informed decisions. The media portray her strong viewpoints as "tyranny" and "despotic" behavior (see Steyrer, 1998: p. 816). This is illustrated in an article in Helsingin Sanomat (Teittinen, 2017), in which Huhtasaari's personality and actions as a party leader are positioned in a negative context by paraphrasing anonymous sources from the Finns Party. One of the anonymous quotes ascribed Huhtasaari as: "Charismatic, luminous, brilliant performer. Determined. On the other hand, stubborn, more on the surface than actual content, politician of only a few topics" (Ibid.). Here Huhtasaari's authority is directly called into question by suggesting that she rides on a couple of populist topics. Moreover, describing her as "stubborn" suggests that Huhtasaari's gender performance eradicates the double-bind-her determination turns into "stubbornness"; hence, it is the wrong kind of masculinity. Another anonymous quote presented in the article describes how Huhtasaari's "way of doing politics is the so-called 'my way or the highway' [English in original], and further continues to frame her as a person with black-and-white thinking" (Ibid.). The quote serves to rely on the imagery of Huhtasaari as someone who is unwil- 
ling to compromise or change her view. These representations serve to diminish Huhtasaari's charismatic nature.

Distrust is generated by presenting her views as causing fear. Yle (Kinnunen, 2018) reports the following:

In the presidential contest, Laura Huhtasaari's task is to make sure that True Finns does not disappear from the political scenery of Finland. Huhtasaari, who declares her own truth by certainty of faith, has good readiness for this.

Huhtasaari divides opinions both in the public marketplace and in Parliament. Her supporters praise her as a charismatic speaker, and opponents bemoan Huhtasaari's frightening speeches.

The reference to "her own truth" conveys the idea that Huhtasaari's beliefs are not commonly shared, implying she is indoctrinating the public. The dark side of her charisma appears in efforts to convey the supposed fears that her message elicits.

\subsection{The Impossible Marriage of Politics and Religion}

Another strategy through which Huhtasaari's credibility and authoritativeness are called into question entails referring to her religious views:

"Huhtasaari has opposed (the) gender-neutral marriage act, compulsion of Swedish language, and adoption rights for same-sex couples. In addition, she does not believe in evolution theory" (Virtanen \& Tikkala, 2017).

The above quote shows how a typical media strategy involves presenting these possibly stigmatizing aspects in a list-like format. In that approach, Huhtasaari's stigma is conveyed by listing all the aspects that are likely to cause some doubt and mistrust among voters.

A Helsingin Sanomat (Vartiainen, 2017) interview states how "Huhtasaari resists same-gender marriage, and the adoption rights of same-sex couples. Even evolution theory is wrong, god created the world-through miracles (...)." The laconic expression "Even evolution theory is wrong", frames Huhtasaari as a person who stands in opposition to most of the views and values, that are considered "normal".

The media deploy irony and exemplification as strategies to illustrate Huhtasaari's personal and political beliefs as irrational and extreme. Thus, the media operate on "intelligence" prototypicality by portraying Huhtasaari as "other-worldly," "tunnel-visioned," and "badly informed" (see Steyrer, 1998: p. 816). Huhtasaari's negative image (stigma) is enforced through the stigma of religion. Religion emerges in stories as a means to denigrate her image as a serious politician (i.e., she believes in odd, irrational things).

Helsingin Sanomat (Junkkari, 2017) brings up Huhtasaari's claim that Finland would be conquered within one day if Russia were to attack:

$$
\text { (...) }
$$


And she has been labelled quite a holy roller, particularly since a few years back, when she said she does not believe in evolution.

"If a frog turns into a prince, it's a fairy tale, but when a frog turns into a prince after years and years, it's science," Huhtasaari wrote on Facebook.

Creationism is the most peculiar part of Huhtasaari's politician image. In (the) US, debating evolution is commonplace in politics, but in Lutheran Finland, it is mostly weird.

Huhtasaari denies strongly that she would have (borrowed) the theme from right-wing Christians. "I don't (borrow) anything. This is what I believe," she says.

"I have been in faith since childhood."

The use of certain descriptive terms ("holy roller" and "weird") in the excerpt above emphasizes how Huhtasaari is viewed as breaking social norms. Often, reports about Huhtasaari bring up her religious beliefs, reinforcing an image of her as "other-worldly" (Steyrer, 1998: p. 816). In the above quote, she rejects associations to right-wing Christians by explaining her religious faith as something that is a natural part of her identity. Thus, she responds to stigma by normalizing her beliefs, evoking tradition, and stating that she has grown up with these views.

The use of Huhtasaari's religion also appears in more indirect ways; articles about her often use religious metaphors, as in the quote below from an Yle article (Kinnunen, 2018):

"The blue and white populist speaks black-and-white" [subheading] Huhtasaari's official opening of her presidential campaign at the beginning of December in the ballroom of Kirjan Talo in Helsinki was devotions staged as a blue-and-white patriotic nationalist occasion.

This excerpt shows how Huhtasaari's religious beliefs and her personality traits are, once again, drawn to emphasize her "tunnel-visioned" nature. The repeated metaphorical references to Huhtasaari's religion are a way to emphasize her deviation from mainstream Finnish political parties. Perhaps, it is also a way to keep alive the narration of the Finns Party as defending conservative, Christian, values, as Timo Soini, the former party chair, has also spoken openly about his religious principles.

\subsection{The Woman with an Inappropriate Smile}

Finally, we found that the stigmatization of Huhtasaari occurred not only through her political or religious views or her competence as a political leader; it was also constructed by addressing the controversies in how she expressed her emotions. Huhtasaari's emotional expressions, particularly her smiles, have been written about in the media:

Huhtasaari speaks fast and a lot. She smiles and laughs in between her words. The topic changes swiftly. 
But even she becomes more earnest when talking about the Tuesday when the Finns Party split (Vartiainen, 2017).

One possible interpretation of the quote presented above is that it reinforces an image of Huhtasaari as indifferent and impulsive.

In another Helsingin Sanomat (Junkkari, 2017) article, the headline is: "Laura Huhtasaari speaks tough, but smiles nicely and emphasizes her maternity-the image has been copied from Marine Le Pen and other right-wing populist women." In this article, the journalist paraphrases Huhtasaari's speech in Parliament:

(...)

"Huhtasaari used harsh language, but smiled happily."

She called out her former party colleagues, governmental partners, and the president by name, using phrases, such as "twisting the truth," "rancid play," "defector government", and "nonsense excuses". She articulated her thoughts eloquently, in an overly enunciated, clear manner to stress the key aspects of her speech:

"Oh my, for this dou-ble stan-dard be-ha-vi-or!" Huhtasaari stated, and smiled.

She was full of triumph, the certainty of being right.

(...)

This quote shows how a stigmatizing and negative depiction occurs through ridicule (Marx Ferree, 2004). It provides a detailed description of Huhtasaari's articulation, and it portrays the contradiction in her emotional expression in comparison to the content of her speech by referring to her as smiling. The phrase, "and smiled", laconically draws the reader's attention to her smiling when she is name-calling her colleagues. Thus, her expression of a positive emotion through smiling is portrayed as breaking social norms (Creed et al., 2014), i.e., smiling in an inappropriate situation. This illustrates that stigmatized groups are sanctioned for emotional displays, suggesting a gender-based treatment differential in such displays (e.g., Voronov, 2014). Prior studies on female political leaders have shown how women suffer from this double-bind, i.e. they are doomed to fail as they try to meet the gender expectations as a woman and as a "fit" member of party in the masculine context (Eagly \& Carli, 2007). Yates (2019), for example, shows how Theresa May is sanctioned by the media for her "unnatural" lack of empathy. In similar, we see here how Huhtasaari is sanctioned by her failure to "properly" perform the emotional labor required of her. She appears to fail to offer the right kind of feminine empathy needed to balance her masculine behavior; hence, she suffers from the double-bind.

\section{Resisting Stigma: Emphasizing One's Role as a Patriotic Warrior}

We also addressed how Huhtasaari attempted to counter-attack some of the key 
stigmatizing arguments raised against her and the Finns Party.

\section{Passionate Defender of Patriotic and Family-Centered Values}

In Huhtasaari's own positioning statements, she uses emotional strategies that emphasize her passion and dedication to the values found in her political agenda. Her discourse also addresses traditional values, and it can be interpreted as a form of emotional affection:

Huhtasaari admits that there are very few conservatives like her in Finland. "But I don't get angry if someone disagrees with me. I don't disown them. Two people who knew my stand toward gay people have disowned me" (Vartiainen, 2017).

This excerpt shows how Huhtasaari avoids the stigma of a marginalized position by emphasizing her own flexibility and desire to collaborate with others. This can be viewed as an example of coping with stigma by emphasizing one's own morality (e.g., Toyoki \& Brown, 2013).

In a story featured in Helsingin Sanomat (Junkkari, 2017), Huhtasaari is given the opportunity to respond to some of the common accusations about her political viewpoints. When asked if she "provokes on purpose", Huhtasaari replies:

"I don't provoke on purpose. I like to challenge. I enjoy discussion. I don't have a problem with people disagreeing with me. In every single party, there needs to be some opposition-otherwise, it won't be healthy."

In this quote, Huhtasaari uses the advocacy strategy by reframing the negative interpretation of "provoking" into a more positive meaning of "challenging": " $I$ don't provoke on purpose. I like to challenge. I enjoy discussion."

Later in the interview, Huhtasaari continues to respond to the suggestions that she is imitating Marine Le Pen:

"I never imitate anyone, and it would not even be possible."

"Now I have been accused of being a Trumpina (proponent of Donald Trump). First, the US has a different kind of history, language. It is an enormously huge country. Trump is Trump, and Laura is Laura. I don't believe that you can attain anything by imitating others."

(...)

"The women of my generation do not fear men, and we dare to question things. We dare to fulfill ourselves. The future defenders of patriotism, conservatism, and nationalism are women. The future warriors are women. Sure, there are men as well. Women have that kind of a common sense in these matters."

"It is away from my children. This is a mother talking. It is away from my children. I believe in over-generational, there is an over-generational 'we.' I am responsible for the future generations, and the generations before us."

The lengthier extract shows how Huhtasaari draws on largely individualistic 
positioning (denying the idea that she has copied her political views from others), which allows her to distance herself from the stigmatized others (Le Pen and Trump). Her implied support for Trump associates anti-Trump sentiments to Huhtasaari; thus, by emphasizing her individuality, Huhtasaari is able to downplay the stigma by association. Even though Huhtasaari rejects the idea of imitating Marine Le Pen, she engages with gender performances that are typically associated with right-wing female leaders, i.e., emphasizing female power and maternal responsibility; for similar findings on traditional media representation of right-wing female leaders see Downing (2018). This offers Huhtasaari the opportunity to reject the possibly negative label of her far-right politics by emphasizing her maternal nature, thereby relying on "coveted social roles" (e.g., Toyoki \& Brown, 2013). Huhtasaari's elected strategy parallels earlier studies on right-wing female leaders. Geva (2020) shows how party members of the French National Rally, and Marine Le Pen herself, create Le Pen's gender performance as a perfect balancing of hegemonic feminine and masculine virtues. Occupying positions as strong female warriors and caring mothers of the nation are strategies that are typically used by right-wing female leaders (Geva, 2020). These can be seen as attempts to evoke positive emotions among media audiences.

\section{Discussion}

Our study examined the discursive mechanisms of stigmatizing and coping with stigma using a recent example from the field of politics. More specifically, this paper addressed the dialectics between stigma and charisma by examining media coverage of right-wing populist leadership in the Finnish news media. The study also examined stigmatizing and stigma-management strategies through the lens of emotions, building on organizational and managerial identity work. The findings illustrate that, in the Finnish context, expressing radical nationalist ideas and religious beliefs is the main foundation for stigmatization. In representing Laura Huhtasaari, the two analyzed media outlets drew on nationalism and religion as the main causes of stigma. Moreover, these media outlets questioned her knowledgeability to erode her status as an influential and serious political leader. This study on the news media's discursive stigmatizing practices contributes to earlier empirical analyses of stigma by addressing the importance of emotional stigmatizing - particularly by analyzing the stigmatized target's emotional expressions to emphasize the contradictory nature of her behavior in light of social norms. Thus, we shed light on how bodily expressions of emotion are interpreted and can be used to construct stigma. We discuss our findings in more detail below.

First, our analysis shows that stigmatizing political leadership occurs around four particular aspects: 1) political opinions (moralization of socially controversial, far-right, nationalist views); 2) personal beliefs (targeting Huhtasaari's image as a serious and stable politician by drawing on personal-level stigmatization of religious beliefs);3) political competence (emphasizing the narrow and aim- 
less focus of Huhtasaari's political agenda, and highlighting her "radical ideas," implying they are illegitimate); and 4) behavior in social situations (emotional reactions that breach social norms). In the case of Huhtasaari, the media predominantly drew on negative representations of her far-right, nationalist views, scrutinizing the morality of her opinions, as well as emphasizing the "irrationality" of her personal beliefs. Moreover, her political competence was questioned. At an emotional level, stigmatizing entails eliciting "fear," "shared ridicule", and concern concerning Huhtasaari's political agenda and her personal beliefs. Thus, the news media's stigmatizing practices eroded the image of the populist leader as a reliable leader, raising concerns about her political leadership's impact on national security and stability.

The use of religion seems particularly interesting. Speaking about one's religious faith has not been common in Finland, and it provides an interesting avenue by which examine the stigmatizing aspects of religion in the context of Finnish political leadership. Examples from the US have addressed how Mitt Romney experienced the stigma of Mormonism during the 2012 presidential campaign (Salek, 2014). In the Finnish context, being a conservative-minded Lutheran is a possible source of stigma. For example, Päivi Räsänen, the Finnish Member of Parliament (MP) and leader of the Christian Democratics Party, has been severely criticized for her public opposition of same-sex marriage and conservative views of the right to abortion. How might expressing religious views affect the evaluation of business leaders? The social construction of stigma is culture-bound; thus, we need to address the national characteristics that set social norms for appropriate behavior in different social and cultural settings.

News articles created a portrait of Huhtasaari that combined charisma with stigma. While, on some occasions, Huhtasaari was portrayed as a strong political figure, other times, her strength was interpreted negatively by portraying her as a militant character-someone to be feared. Previously, we discussed how the "warrior of the party" is represented as a militant, tunnel-visioned nationalist. Thus, this paper illustrates that the media can imbue the charisma of political leadership with negative meanings. Our paper also shows how the Finnish news media's representation of a right-wing populist party leader, as well as the party leader's own responses, intersects with the creation of a threat society (see Nohrstedt, 2010). While Huhtasaari relied on tactics that aimed to portray her as a positive, independent leader, or "heroine" (associating positive meanings with the "mother" and "female warrior" figure), the media approached her charismatic image by polarizing it as "dark" charisma, i.e., militant and dogmatic. Huhtasaari's choice of presentation is understandable in light of right-wing party voters' behavior; Laustsen and Petersen (2019) show that right-wing party voters prefer a dominant leader that can show strength and masculinity.

The study's findings also support Bos et al.'s (2010: p. 159) argument that authoritativeness may be more relevant for right-wing populist party candidates, enabling them to achieve success. The Finnish media's stigmatizing discourse re- 
lied heavily on eroding and questioning the authoritativeness and legitimacy of the presidential candidate's beliefs and claims. Thus, the findings emphasize the importance of the leader's competence and knowledge of the issues at hand in the context of the current Finnish political scene. The findings suggest that right-wing populist leaders might benefit from the use of credible sources when citing evidence, as well as fact-based arguments when granting interviews to the media.

Huhtasaari drew on stigma-management strategies that employed distancing and rejection, advocacy of her individual beliefs, and embedding her beliefs within traditional and family-centered values. She also drew on the naturalization of her own beliefs, rather than apologizing for them. While extant stigma literature has pointed to shame and guilt among the stigmatized, these were absent in the present study's case. Our study found that the media and the stigmatized party leader (Huhtasaari) drew on very different kinds of strategies and emotions. While the media relied on "shaming" and ridicule, Huhtasaari did not directly confront these aspects of her negative image. Rather, she elected to use different strategies that shifted the discussion to other topics. Distancing is a typical discursive strategy that the populist Finns Party has used to respond to negative accusations in the media (Hatakka et al., 2018). Huhtasaari attempts to draw attention from the tunnel-visioned stigma of her personality and assign positive meaning to her nationalist views. Such visualizations aim to elicit empathy and other positive reactions among voters. While the media represented Huhtasaari through stigmatizing attributes that drew attention to her dogmatic ideas about immigration and emphasized her militant attitudes on protecting Finnish national interests, her own impression management strategies eschewed the stigmatized position through moral claims, as well as presenting herself as a strong leader for change. Altogether, Huhtasaari's discourse emphasized her appreciation of strong political leadership and courage to make changes. Thus, her discourse included attempts to convey the attributes of charismatic leadership instead of stigma. In the analyzed media articles, we found that Huhtasaari and others from the Finns Party only made a few direct references to their stigmatized positions; instead, they ignored negative questions and focused on emphasizing their own political agenda.

This study addressed some of the gendered aspects of stigmatizing. Our findings shed further light on earlier research, which found that conservative female political leaders (Mendoza \& DiMaria, 2019; Yates, 2019) and right-wing female leaders (Downing, 2018) suffer from normative gender expectations. While Huhtasaari was stigmatized due to her inappropriate gender performances (smiling at inappropriate times and being too stubborn), she sought to utilize narrations of femininity and masculinity to gain legitimacy. This shows how right-wing female leaders are placed in a situation where they are required to manage their gender identities within the complex expectations of their right-wing voters, as well as within the context of wider societal expectations. Our findings suggest that there is a need to further examine how female 
political leaders are sanctioned and stigmatized on the basis of their emotional labor. Future studies could benefit from examining possible gendering in the use of stigmatized groups/individuals' expressions of emotions. How male and female right-wing leaders are stigmatized in the media, and what types of self-representation they draw on to manage the stigmatized identities remain questions for future studies.

Steyrer's model proved useful in examining stigmatization and coping with stigma. Similar empirical studies would be relevant in a business context as well. For example, regarding the rise and popularity of human-centric leadership and soft leadership skills, it could be interesting to examine how the so-called "hard" authoritative leadership style might ascribe negative attributes to a leader or how concentrating on monetary values as a key way to lead a business might be viewed as being detrimental.

Our paper also contributes to extant literature of populist parties' management of their media relations (e.g., Hatakka et al., 2018) by examining stigma-management strategies and their emotional appeal to audiences. However, our analysis of stigma-management strategies is biased due to the nature of our data. One must bear in mind that the news media control how Huhtasaari's voice is portrayed in their articles. In the future, interviews with party leaders would provide more in-depth access to their perceptions of being the targets of stigmatization. Finally, this study's findings also provide a rationale for raising some ethical concerns about the role of media in shaping public perceptions of leaders and favoring particular leadership types. In the future, it would be useful to compare the reporting styles and tones that Finnish media use with different political parties.

\section{Conclusion}

To conclude, this paper has addressed the (de)stigmatization of political leadership in the case of a right-wing populist presidential candidate in the press media. We have approached right-wing populism in the media through the lens of stigma and emotions, in order to further the understanding of the tensions revolving around right-wing populist leadership and their media representation.

\section{Conflicts of Interest}

The authors declare no conflicts of interest regarding the publication of this paper.

\section{References}

Abramson, K. (2013). A Sentimentalist's Defense of Contempt, Shame, and Disdain. In E. Goldie (Ed.), The Oxford Handbook of Philosophy of Emotion (pp. 188-213). Oxford: Oxford University Press.

Anspach, R. R. (1979). From Stigma to Identity Politics: Political Activism among the Physically Disabled and Former Mental Patients. Social Science and Medicine, 13A, 766-773. https://doi.org/10.1016/0271-7123(79)90123-8 
Arter, D. (2020). When a Pariah Party Exploits Its Demonised Status: The 2019 Finnish General Election. West European Politics, 43, 260-273. https://doi.org/10.1080/01402382.2019.1635799

Bos, L., van der Brug, W., \& de Vreese, C. (2010). Media Coverage of Right-Wing Populist Leaders. Communications, 35, 141-163. https://doi.org/10.1515/comm.2010.008

Bos, L., van der Brug, W., \& de Vreese, C. (2011). How the Media Shape Perceptions of Right-Wing Populist Leaders. Political Communication, 28, 182-206. https://doi.org/10.1080/10584609.2011.564605

Bryman, A., \& Bell, E. (2011). Business Research Methods (3rd ed.). Oxford: Oxford University Press.

Chilton, P. (2004). Analysing Political Discourse: Theory and Practice. Abingdon-on-Thames: Routledge. https://doi.org/10.4324/9780203561218

Creed, D. W., Hudson, B. A., Okhuysen, G. A., \& Smith-Crowe, K. (2014). Swimming in a Sea of Shame: Incorporating Emotion into Explanations of Institutional Reproduction and Change. Academy of Management Review, 39, 275-301.

https://doi.org/10.5465/amr.2012.0074

Downing, L. (2018). The Body Politic: Gender, the Right Wing and "Identity Category Violations". French Cultural Studies, 29, 367-377. https://doi.org/10.1177/0957155818791075

Eagly, A. H., \& Carli, L. L. (2007). Women and the Labyrinth of Leadership. Harvard Business Review, 85, 62-71.

Finns Party (2018). https://www.perussuomalaiset.fi/kielisivu/in-english

Geva, D. (2020). Daughter, Mother, Captain: Marine Le Pen, Gender, and Populism in the French National Front. Social Politics, 27, 1-26.

Goffman, E. (1963). Stigma: Notes on the Management of Spoiled Identity. Upper Saddle River, NJ: Prentice-Hall.

Goode, E., \& Ben-Yehuda, N. (2009). Moral Panics. The Social Construction of Deviance. Hoboken, NJ: Blackwell Publishing. https://doi.org/10.1002/9781444307924

Hatakka, N. (2018). Liittolaisia ja vastuksia: Neljä näkökulmaa populismin ja median suhteeseen. In M. K. Niemi, \& T. Houni (Eds.), Media \& populismi. Työkaluja kriittiseen journalismiin (pp. 31-53). Vastapaino.

Hatakka, N., Niemi, M. K., \& Välimäki, M. (2018). "Perussuomalaiset ei ole rasistinen puolue” Näin populistipuolue vastaa rasismisyytöksiin mediassa. In M. K. Niemi, \& T. Houni (Eds.), Media \& populismi. Työkaluja kriittiseen journalismiin (pp. 119-145). Vastapaino.

IRO Research (2017). Sanomalehdillä selkeä ykkösasema luotettavuudessa. https://www.sanomalehdet.fi/ajankohtaista/sanomalehdilla-selkea-ykkosasema-luotetta vuudessa/

Junkkari, M. (2017). Laura Huhtasaari puhuu kovia mutta hymyilee kivasti ja korostaa äitiyttään imago on kopioitu Marine Le Peniltä ja muilta oikeistopopulistinaisilta. Helsingin Sanomat. http://hs.fi/sunnuntai/art-2000005331138.html

Kinnunen, P. (2018). Henkilökuvassa Laura Huhtasaari: Kun maailma mureni kolmessa päivässä. Yle. http://yle.fi/uutiset/3-9986024

Koivunen, A. (2008). Affektin paluu? Tunneongelma suomalaisessa mediatutkimuksessa. Tiedotustutkimus, 3, 5-24. https://doi.org/10.23983/mv.63018

Koopmans, R. (2005). Repression and the Public Sphere: Discursive Opportunities for Repression against the Extreme Right in Germany in the 1990s. In C. Davenport, H. 
Johnston, \& C. Mueller (Eds.), Repression and Mobilization (pp. 159-188). Minneapolis, MN: University of Minnesota Press.

Laustsen, L., \& Petersen, M. B. (2019). Why Are Right-Wing Voters Attracted to Dominant Leaders? Assessing Competing Theories of Psychological Mechanisms. Leadership Quarterly, 31, Article ID: 101301. https://doi.org/10.1016/j.leaqua.2019.06.002

Linden, A., \& Klandermans, B. (2006). Stigmatization and Repression of Extreme-Right Activism in the Netherlands. Mobilization: An International Journal, 11, 213-228. https://doi.org/10.17813/maiq.11.2.t87425625ltr5151

Link, B. G., Yang, L. H, Phelan, J. C., \& Collins, P. Y. (2004). Measuring Mental Illness Stigma. Schizophrenia Bulletin, 30, 511-541.

https://doi.org/10.1093/oxfordjournals.schbul.a007098

Marx Ferree, M. (2004). Soft Repression: Ridicule, Stigma, and Silencing in Gender-Based Movements. Research in Social Movements, Conflicts and Change, 25, 85-101. https://doi.org/10.1016/S0163-786X(04)25004-2

Mendoza, S. A., \& DiMaria, M. G. (2019). Not "With Her": How Gendered Political Slogans Affect Conservative Women's Perceptions of Female Leaders. Sex Roles, 80, 1-10. https://doi.org/10.1007/s11199-018-0910-z

Niemi, M. K., \& Houni, T. (2018). Media \& Populismi. Työkaluja kriittiseen journalismiin. Vastapaino.

Niilola, M. (2017). Kuka on perussuomalaisten presidenttiehdokkaaksi ehdotettu Laura Huhtasaari? Yle. http://yle.fi/uutiset/3-9758144

Nohrstedt, S. (2010). Threat Society and the Media. In S. A. Nohrstedt (Ed.), Communicating Risks. Towards the Threat Society? (pp. 17-52). Göteborg: Nordicom.

Roslund, R. (2018). Huhtasaarella loppui osaaminen ulko-ja turvallisuuspolitiikan asiakysymyksissä "rukousaamiaisen mainitseminen ulkopoliittisena meriittinä ei vähentänyt mielikuvaa”. Yle. https://yle.fi/uutiset/3-10011210

Säävälä, H. (2017). “Järkyttävää”, “epämiellyttävää puhetta”, “vaarallista” puoluejohtajat kommentoivat perussuomalaiseten Huhtasaaren islamisaatiopuheita. Yle. http://yle.fi/uutiset/3-9823551

Salek, T. A. (2014). Faith Turns Political on the 2012 Campaign Trail: Mitt Romney, Franklin Graham and the Stigma of Nontraditional Religions in American Politics. Communication Studies, 65, 174-188. https://doi.org/10.1080/10510974.2013.851097

Scheff, T. J. (1998). Shame in the Labeling of Mental Illness. In P. Gilbert, \& B. Andrews (Eds.), Shame: Interpersonal Behavior, Psychopathology, and Culture (pp. 191-205). Oxford: Oxford University Press.

Silfverberg, K. (2017). Laura Huhtasaaren menestys presidentinvaaleissa on varma asia. Helsingin Sanomat. http://hs.fi/politiikka/art-2000005359186.html

Snipes, A., \& Mudde, C. (2019). "France's (Kinder, Gentler) Extremist”: Marine Le Pen, Intersectionality, and Media Framing of Female Populist Radical Right Leaders. Politics \& Gender, 16, 438-470. https://doi.org/10.1017/S1743923X19000370

Snow, D. A., \& Anderson, L. (1987). Identity Work among the Homeless: The Verbal Construction and Avowal of Personal Identities. American Journal of Sociology, 92, 1336-1371. https://doi.org/10.1086/228668

Steyrer, J. (1998). Charisma and the Archetypes of Leadership. Organization Studies, 19, 807-828. https://doi.org/10.1177/017084069801900505

Suomen Uutiset (2018). Laura Huhtasaaren kolmas sija presidentinvaalissa on perussuomalaisten kaikkien aikojen paras sijoitus.

https://www.suomenuutiset.fi/laura-huhtasaaren-kolmas-sija-presidentinvaalissa-on-p 
erussuomalaisten-kaikkien-aikojen-paras-sijoitus

Takala, T., Tanttu, S., Lämsä, A.-M., \& Virtanen, A. (2013). Discourses of Charisma: Barack Obama's First 6 Months as the President of the USA. Journal of Business Ethics, 115, 149-166. https://doi.org/10.1007/s10551-012-1389-0

Taub, D. E., MCLorg, P. A., \& Fanflik, P. L. (2004). Stigma Management Strategies among Women with Physical Disabilities: Contrasting Approaches of Downplaying or Claiming a Disability Status. Deviant Behavior, 25, 169-190.

https://doi.org/10.1080/01639620490269012

Teittinen, P. (2017). Laura Huhtasaari on "normaalia” Suomea kaipaava kiihkeä konservatiivi, joka veisi ulkopolitiikan tiukasti Sveitsin linjalle. Helsingin Sanomat. http://hs.fi/politiikka/art-2000005507130.html

Toubiana, M., \& Zietsma, C. (2017). The Message Is on the Wall? Emotions, Social Media and the Dynamics of Institutional Complexity. Academy of Management Journal, 60, 922-953. https://doi.org/10.5465/amj.2014.0208

Toyoki, S., \& Brown, A. D. (2013). Stigma, Identity and Power: Managing Stigmatized Identities through Discourse. Human Relations, 67, 715-737.

https://doi.org/10.1177/0018726713503024

van Der Brug, W., \& Mughan, A. (2007). Charisma, Leader Effects and Support for Right-Wing Populist Parties. Party Politics, 13, 29-51. https://doi.org/10.1177/1354068806071260

van Spanje, J., \& Azrout, R. (2018). Tainted Love: How Stigmatization of a Political Party in News Media Reduces Its Electoral Support. International Journal of Public Opinion Research, 31, 283-308. https://doi.org/10.1093/ijpor/edy009

Vartiainen, N. (2017). Perussuomalaisten Laura Huhtasaari kertoo nyt miltä tuntuu kun puolue hajoaa "Haava kyllä arpeutuu”. Helsingin Sanomat. http://hs.fi/politiikka/art-2000005266278.html

Virtanen, J., \& Tikkala, H. (2017). Laura Huhtasaari valittiin perussuomalaisten presidenttiehdokkaaksi. Yle. http://yle.fi/uutiset/3-9848198

Voronov, M. (2014). Toward a Toolkit for Emotionalizing Institutional Theory. In N. M. Ashkanasy, W. J. Zerbe, \& C. E. J. Härtel (Eds.), Research on Emotion in Organizations: Emotions and the Organizational Fabric (Vol. 10, pp. 167-196). Bingley: Emerald Group Publishing. https://doi.org/10.1108/S1746-9791 20140000010015

Wodak, R., \& Chilton, P. (2005). A New Agenda in (Critical) Discourse Analysis: Theory, Methodology and Interdisciplinarity. Amsterdam: John Benjamins Publishing. https://doi.org/10.1075/dapsac.13

Yates, C. (2019). "Show Us You Care!" The Gendered Psycho-Politics of Emotion and Women as Political Leaders. European Journal of Politics and Gender, 2, 345-361. https://doi.org/10.1332/251510819X15646233470674 